\title{
Public Finance Sustainability in Romania - Challenges and Vulnerabilities
}

\author{
Ionel BOSTAN 1*, Carmen TODERAȘCU ${ }^{2}$, Anca Florentina GAVRILUȚĂ ${ }^{2}$ \\ ${ }^{1}$ Faculty of Law and Administrative Sciences, Stefan cel Mare University of Suceava, 13 Universităţii, 720229 \\ Suceava, Romania; \\ ${ }^{2}$ Faculty of Economics and Business Administration, Alexandru Ioan Cuza University of Iasi, 11 Carol I, 700506 \\ Iaşi, Romania. \\ *Correspondence: ionel_bostan@yahoo.com or ibostan@fdsa.usv.ro
}

\begin{abstract}
Given the contradiction between the current demands for sustainability and the way the financial system works, this paper explores in a retrospective and a prospective view the Romanian Public Finance Sustainability, highlighting the major challenges and vulnerabilities. For the retrospective part, we concentrate mainly on empirical tests on Romanian government solvency between the period 1986-2016, by applying unit root and co-integration tests. To gain a better, general understanding of the behavior of policy-makers, in the second part we use a scenario analysis of budgetary adjustment in the short and medium run under alternative hypotheses. The results provide a formal proof that policy makers decisions face critical and complex questions and the way in which they manage fiscal stimuli have a direct implication on the sustainability of the country and on the lax implementation of fiscal policy.
\end{abstract}

Keywords: fiscal sustainability; public finance; fiscal consolidation; fiscal responsibility

\section{Introduction}

Current global fiscal governance issues and the area of public finances involve a growing number of challenges on the world stage, which are spreading across Europe. Even if over the last two decades, the theoretical and empirical literature on public finances and sustainability of fiscal policy has steadily increased the controversy and the desire to strengthen government accountability mechanisms, the problems from this area keep increasing especially since 2008-2009, with the manifestation of the economic crisis. Also, current macroeconomic context is characterized by decisions based on tough political stakes, which makes oscillation in tackling anti-cyclical or procyclical policies have an important implication on the sustainability of public finances. So, is appropriate to conduct an analysis of fundamental elements involving challenges and vulnerabilities in fiscal policy, which can reveal the need for accountability of decision-makers and implicitly, better correlation of their decisions with the finality of the actions taken.

Most empirical investigations of fiscal sustainability focus on testing the assumption of cointegration between government revenues and expenditures, identifying at the same time a preference for application of unit roots in government debt and budget deficit series. In line with above, given the fact that modernity intervenes with major changes on this branch and the central element of analysis falls to the notion of accountability, at the global level, we also find a preference and a necessity to study the relationship between public finance sustainability and Fiscal Responsibility Laws (FRLs). 
According to recent estimates, policy makers across the world have approached several public policies for consolidate new fiscal rules framework, but do not consider the changes that have taken place over time. In the conditions of a progressive deterioration of the primary balance under the exclusive impact of demographic factors, the sustainability of public finances may be more difficult to assure. As highlighted by Chan-Lau et al and Santos et al. [1,2], the main idea of the notion of sustainability has deeply changed. If many years ago the phenomenon of public finance sustainability was analyzed by addressing rising budget deficits or the level of public debt as a percentage of GDP, contemporaneity brings into discussion demographic elements, phenomenon of ageing population, consequently with the increasing spending on pensions and all social obligations which derives from this. In this case, we find that fiscal policy is sustainable when the government debt growth rate is lower than the long-term interest rate, considering that a sustainable fiscal policy is one that does not lead to: excessive increase in indebtedness; drastic reduction of budget expenditures and/or significant increase of taxes; monetization of the budget deficit or repudiation of contracted public debt [2].

Considering the above discussion, we can say that the implications of the normative and political framework and the preferences for procyclical or anti-cycle policy imply an unwanted confrontation of the public finance with the test of facts and as a result, it implies a direct manifestation on society. As the current problems related to the fiscal indiscipline and the lack of solidity of the public financial policies are known to be expanding both at European and international level, it is appropriate to address the issue regarding the sustainability of Romanian fiscal policy, precisely because an unsustainable fiscal position have a direct impact on macroeconomic stability and is the mirror of future fiscal crisis.

Moreover, it is well known that the Romanian fiscal system is characterized by imbalances that require correction on the direction of inefficient fiscal management and excessive bureaucracy, things that invoke also the needs of a radical reform of the tax collection system to ensure a significant increase in collected revenue and a reduction in the related administrative costs $[3,4,5]$.

In line with above, literature has established two factors that are often cited, the political instability (and political uncertainty) on growth and the relatively high debt level deepen by fiscal deterioration in the aftermath of the global financial crisis started in $2008[6,7,8]$. Because political leaders are often to engage budget process implementation and execution, they may be more sensitive to any impact of legal framework changes from the area of fiscal sustainability or they may be sensitive to any impact speculation in global markets. From this perspective, they can offer different strategies to different economies, considering a preference for an anticyclical or procyclical policy. The main question is how public finance can improve sustainability improve, how changes in income and expense policy manage dynamics of fiscal balance and debt dynamics and, how the strategies can be influenced by the legal framework on the area of fiscal performance. The preference for a fiscal policy type (procyclical or countercyclical) depends also on the economic stage: recession or expansion and this implied different measures from the part of the central authority. Central Authority shall consolidate public finance and ensure long term public finance sustainability, but if the political stake is more important than economic stability of the country, the effect is intergenerational.

As far as we are concerned, we believe that although the inheritance of the crisis and, implicitly, the result of the actions taken at the government level has raised interest in consolidating the sustainability of public finances, it is imperative to position our analytical spirits on the aspects that show us the essence of sustainability, what measures are sustainable or what are the measures that affect sustainability, what ingredients are missing for its consolidation, or what are the conception of it at international level.

The aim of the paper is to provide new evidence on the picture of fiscal sustainability in Romania, to analyze the main challenges and vulnerabilities. Given, the fact that tax policy is considered the state's fiscal policy, being geared toward achieving more or less defined objectives, fiscal policy is an 
important element of the financial policy, especially the economic policy. Decisions adopted in the field of fiscal policy may have a negative impact on the economy of a country, leading to major imbalances through rising inflation or an interest rate. A properly used fiscal policy can drive the economy of a country in favorable directions. So, if there is a question of the impossibility of using fiscal policy to help exit the recession and accelerate economic growth, the parties governing the recessions deepened by the pro-cyclicality of fiscal policies are perceived by the public as being helpless and punished by diminishing the weight in parliament, until the party that governs exclusively in the ascending stages of the business cycle remains without a real opposition.

This paper also contributes to create a comprehensive view on the way in which each of the analyzed Romanian fiscal policy context suffered budgetary adjustment or changes in the macroeconomic circumstance, under the fiscal reforms process. Moreover, it explores a potential connection between fiscal rules/fiscal responsibility law and fiscal policy.

The remaining of this paper is structured as follows: section 1 reviews some of the key literature on the main determinants of public finance sustainability, section 2 refers to the Retrospective Testing of Budget sustainability in Romania: Results of Unit Root and Cointegration Tests, section 3 presents data and explains methodology, the empirical results and their interpretations in base of simulating number of scenarios. Our paper ends with concluding remarks, emphasizing policy recommendations that, in our opinion, should be considered for improving fiscal responsibility and consolidate public finance sustainability.

\section{Theoretical considerations and empirical experience}

Literature on the issue of public finance sustainability reveal that there are few papers examining the link between the way to a sustainable fiscal policy and small permanent or even temporary changes in some important variables, such as interest rate, inflation or demographic changes with the costs of ageing. Some empirical studies have pointed out that both the ex post and the ante post economic crisis period, have been characterized by instability, inadequate decisions and implicitly, wrong model adoption of collective discipline, leading to a fiscal indiscipline over most European countries [9,10,11].

We also find that it is a direct link between the idea or desideratum of sustainable finances and the economic potential of each country, due to the fact that a high level of indebtedness prevents sustainable growth, which has led the specialized literature to address an econometric model to estimate the causality between the sustainability of public debt and economic growth [2-12]. As a rationale that justifies the implication of some variables like ageing costs on public finance sustainability, some authors note that public finance sustainability is synonym with the concept of fiscal sustainability, which is focused on identified the major challenges from this area, in order to better evaluate the debt through some important criteria: liquidity, solvency and realistic adjustment criteria that take into account demographic aspects $[\underline{12,13,14]}$.

Several papers include some empirical approaches concerning public finance sustainability of countries, the most well-known being focused on various and mixed methodology, involving many instruments to measure the sustainability. Referring to the example of some international organizations, on the profile of (IMF), we identify the use of such tools as ALM (Asset and Liability Management) model or the QUEST model developed by the European Commission which is based on the analysis of many variables, who's simulation is relevant only if the primary data entered in the model is correct [1-15]. Other authors [12,16], introduce an Index of Sustainability calculated as the difference between the sustainable tax rate and the effective rate of taxation in the economy. Polito and Wicken, assume a similar approach and propose an Index of Fiscal Stance [13,17]. Other papers focused on analyzed the 
implication of social sector in assessing the sustainability $[\underline{15,18]}$ or demographic perspectives $[\underline{16,19]}$ and population ageing trends [17].

Analyzing the reports of the European Commission, we also identify the incidence of a measure of the purpose of the tax institutions. Thus, according to the data centralized in the Commission's reports, the methodology used in the calculation of this index involves addressing some indicators such as: assessing the Fiscal Council's compliance with the tax rule, implications in fiscal policy monitoring, involvement in correction of correction mechanisms, quantification of policy measures, long-term sustainability. All these indicators are quantified in terms of the importance and implications of the bodies to obtain a final score indicating an index that measures the purpose of the tax institutions. In the light of the Organization for Economic Cooperation and Development (OECD) settlement tribunals, revenue and expenditure balances are trimmed to ensure the sustainability of public finances. In this case, it is believed that if government revenue is high, finances the supply of goods and services, and has a redistributive role, but in long-term revenue and expenditure should be balanced to ensure the sustainability of public finances.

Bergman et al. and Landolfo, performed an empirical analyze on the profile of the Euro Area for the period from 1966 to 2004 and USA for the period 1977-2003. By using cointegration and unit root tests to public debt, primary surplus and interest rates, they evaluate fiscal sustainability and conclude in base of infinite horizon-tests, that both regions have adopted effective policies that have led to a sustainable fiscal policy, the first author also emphasizes the importance of tax rules in consolidating transparent fiscal policies and increasing tax solvency $[18,19]$.

Afonso and Rault $[\underline{20,21}]$, found on the profile of EU-15 that fiscal sustainability has been reached in certain sub-periods, more precisely 1970-1991 and 1992-2006. The author use stationarity and cointegration analysis for the time period from 1970-2006. On OECD profile, Afonso and Jalles 2012 performed also an analysis of the same topic over the period 1970-2010 [22]. Based on unit root and cointegration analysis, they found that fiscal policy also depends on the level of debt, management of revenues and expenditures and in case of some countries, their analysis highlight the existence of a less sustainable fiscal policy. After two years, they improve first paper, by investigating the sustainability of fiscal policy in a set of 19 countries, this time over the period 1880-2009 [23]. The same author, highlight that vulnerability of public debt is influenced by both public debt and debt levels by its profile and characteristics of public debt structure (maturity, currency, lender) need to be approached with great care in analyzing the critical situations that may arise in the management of public debt. A high weight of public debt with short-term initial maturity in total public debt may indicate the country's inability to issues long-term public debt, which increases the vulnerability of risk refinancing and interest rates. A high share of public debt in foreign currency in total public debt may increase the risk rate risk exchange and may exert pressure on currency reserves

On the profile of Romania, we find fewer studies that focus on analyze public finance sustainability. Some researchers such as Boiciuc 2015; Talpo and Enache, 2008 [24,25], attempts to analyze responsibility in terms of monthly values of public revenues and public expenditures, in order to discover the results co-integration test. They found that, as long as public revenues remain unchanged, the public debt path will not change, ensuring long-term stability. Mura 2015; Patricia et al. [26,27]., taking into account the period 2005-2013, analyzes the main component of the budget, referring to tax revenue and concluding that the fiscal consolidation process from this country has numerous vulnerabilities, which lead to a higher risk for fiscal sustainability. This idea is also supported by the reports of the European Commission where it is included in the category of high-risk countries regarding the sustainability of public finances. 
There are also some additional papers that focus on studying the specific elements of fiscal sustainability, like importance of fiscal responsibility and rules or the relationship between public debt, Sovereign Risk and Sustainable Development [28,29]. According to Canagarajah et al. [30] is reveal that fiscal balance of Romania has been deteriorated sharply following the global economic crisis, forcing Romania to implement a unsustainable fiscal consolidation, with a result of unsustainable growth rates, highlighting also the incidence of tax evasion and the inefficiency of fiscal policy. Furthermore, the author stresses that the need for the tax consolidation process to be related to the specifics of our country, taking into account its own fiscal capacity and the link with the macroeconomic context

Radulescu [3], also performed a analyses on Romania profile, by emphasizing the situation of country budget sustainability during the 1990 and conclude that along the transition period, unsustainable fiscal policy has been maintained. We find also that Boiciuc (2015b) [24] investigate the cyclical behavior of fiscal policy in Romania by calculating the structural deficit and the fiscal impulse for 2000-2013, concluding that fiscal policy was generally pro-cyclical, except 2013 year.

In line with above, in 2014, Tița, Oțetea, and Banu (2014) [31] reveal on the profile of our country that Romanian fiscal system should follow aims to increase the quality of public finances, by improving the mechanisms of fiscal stimuli, consolidate fiscal governance and strengthening fiscal discipline. The authors propose legislative and institutional measures, by involving the implication of a new law in area of fiscal responsibility, strict fiscal rules and independent Fiscal Council.

\section{Retrospective Testing of Budget sustainability in Romania: Results of Unit Root and Cointegration Tests}

The global financial crisis has highlighted the importance of understanding the sources of vulnerabilities that can lead to a systemic financial crisis. This reinforces the hypothesis that early identification of vulnerability sources is extremely important as this would allow the introduction of policies with direct implications on the diminution of their effect. In addition, contemporarily show us that the state is an important actor in both political, economic and social life. In terms of the sustainability of the actions undertaken, it is conditional on the procurement of resources, thus using several levers, including the tax system. From the point of view of its status as a public goods supplier and, implicitly, as a public service provider, the state enjoys legitimacy to obtain funding from the beneficiaries concerned. This legitimacy is exerted by public revenue policy, but there is always a need for interdependence between the need for public resources and the state's implications in the delivery of public goods and services. Or, given the fact that financial stability is largely and the result of the stability of public finances, it is increasingly the issue of efficient management of public resources and ensuring the sustainability of finances Taking into account the above, the relationship between financial crisis and public finance sustainability is complex. On the one hand, the crisis has seriously impacted the economies around the world. On the other hand, the failure of governments to respond to the implications of crises leads to a greater need for long-term accountability factors. An important consequence on the above is the current sovereign debt crisis, which affects many countries including members of the European Union (EU) and the euro area. Considering government's decisions in promoting unsustainable growth, with unconsolidated budgets and a large volume of debt, is really important to identifying the right way in managing the difficulties to financing public debt and to consolidate public finances.

Given the fact that this study aims to analyses Romanian fiscal sustainability, taking into account both past events and situations, as well as prospecting the future, we consider appropriate to understanding first, the current public finances and challenges. So, we first analyze the budgetary fiscal situation from the past, namely the last thirty years, by summarizing in Figure 1 the trends that follow macroeconomics and budgetary framework between 1986 and 2016. After this, because the retrospective is not enough, through the prospective approach, we document if the future evolution of fiscal sustainability is negative or positive. 
To test the retrospective part of this study, we applied empirical tests on Romanian government solvency during the last three decades, using standard unit root and co-integration tests. Also, we use a scenario analysis of budgetary adjustment in the short and medium run under alternative hypotheses, in order to highlight the changes that may result from incorrect government decisions or lack of impact on sustainable growth.

Romanian public finances are facing many challenges but given the contemporary conjuncture and the persistence of some variables with a direct implication on future sustainability, we will focus on those that are considered key challenges. These are usually approached at the global level given the fact that are the most common indicators for changes in public finances sustainability. The novelty of our approach is given by the lax research by this type on the profile of this country, the period taken into account and by the mixed models used. Also, the approach highlights and analyze the budgetary costs of ageing, by using the expenditure related with age, which have a direct implication not only on public sector but also on macroeconomic stability. We use data from the EU's AMECO database and Knoema World Data Atlas.

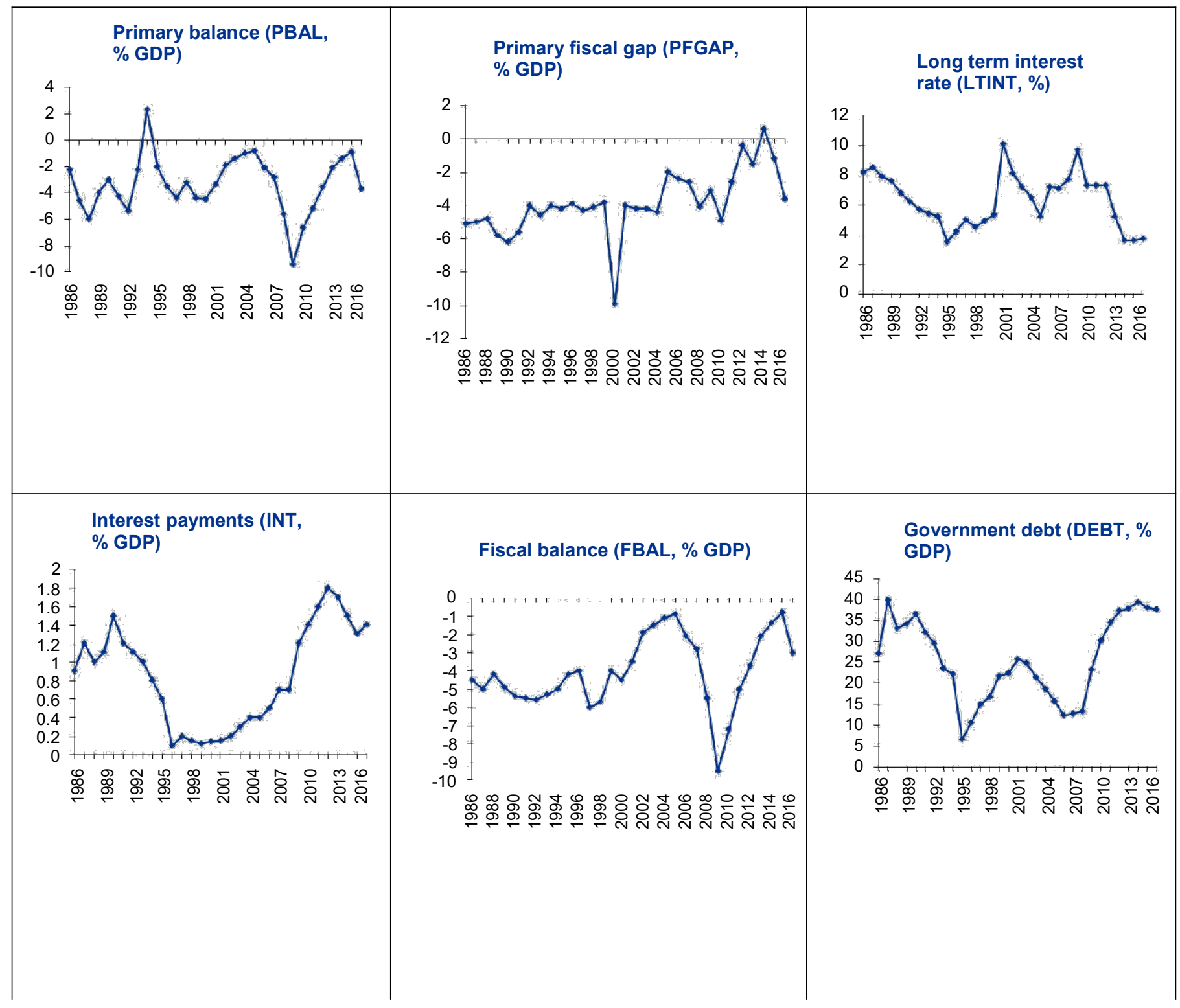




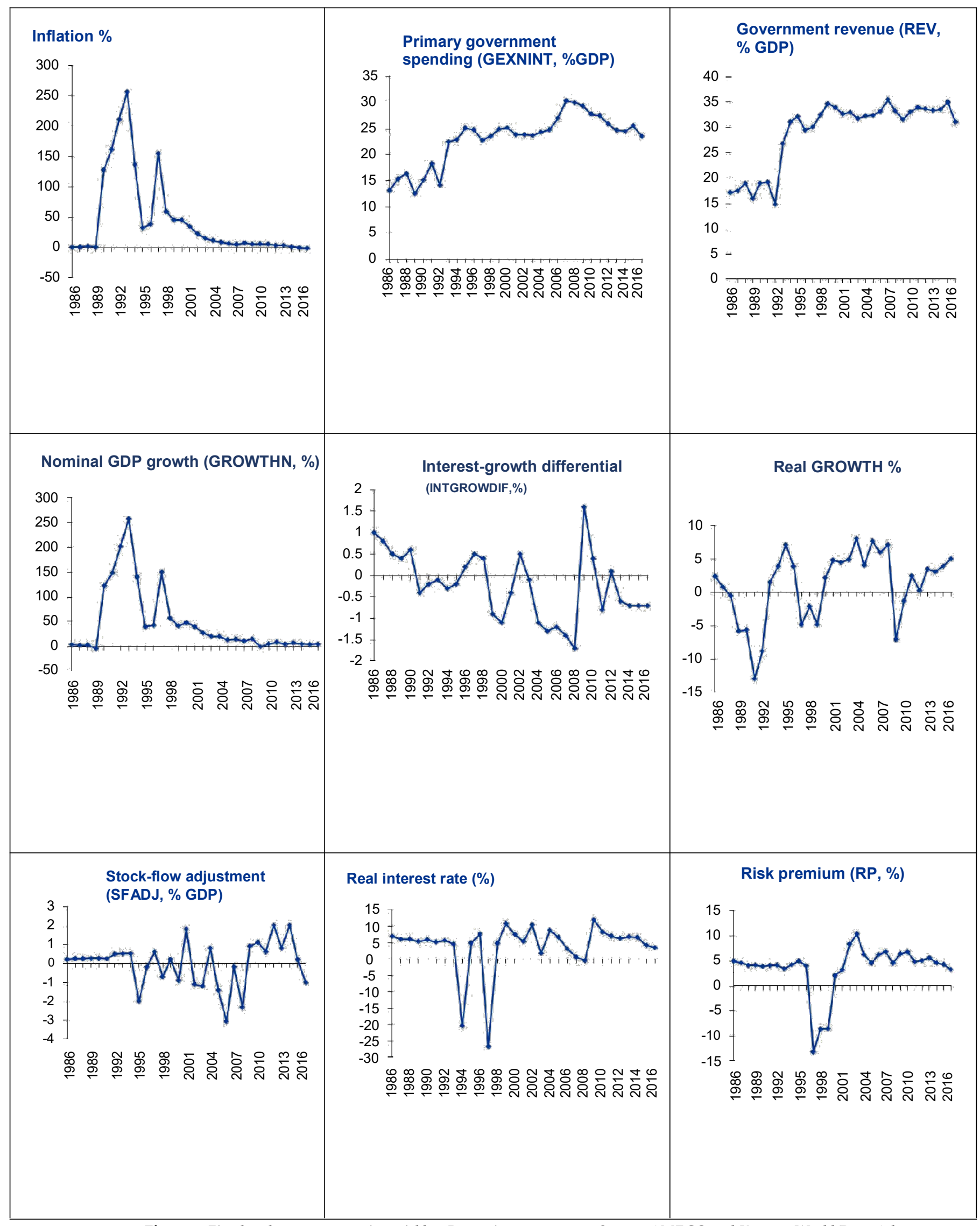

Figure 1 Fiscal and macro-economic variables, Romanian, 1986-2016. Source: AMECO and Knoema World Data Atlas 
Achieving performance with a volatile European and world-wide volatile macroeconomic environment is extremely difficult, especially since there have been a series of events that have marked the world economy: Brexit's, intensification of the refugee crisis, deterioration the slowdown in international trade growth, the modest economic evolutions of the main emerging countries (such as Brazil and Russia) and the rebalancing in China's economy that have contributed to increasing uncertainties about the future developments of the global economy. The picture of Romanian public finance sustainability, highlights a series of major challenges to the sustainability of Romanian public finances, highlighted by both public debt levels and the unsustainable growth rate, accompanied by high inflation in some years.

Given the fact that unsustainable public finance implies a violation of the rules on budget constraints, the literature shows that most empirical studies analyze this topic by estimating stationarity of fiscal balances and on test the cointegration between debt and the primary fiscal balance. Bohn and Afonso [32,9], choose to analyze the subject from the same perspective and test the cointegration between government revenues and government expenditures.

Our aim is to examine if the general political agreements and policy-makers decisions from the area of fiscal policy are really affecting the public finance sustainability over the last three decades. For our sample, in order to test to test whether the Romanian budget was sustainable before and after the communist period and also, in time of fiscal crisis from 2009, we first conduct unit root tests on the variables considered pertinent and listed in the table 2.

Table 1: Unit root test results

\begin{tabular}{|llrr|rr|}
\hline & Deterministics & \multicolumn{2}{c|}{ ADF } & \multicolumn{2}{c|}{ PP } \\
\hline & & t-stat & prob & t-stat & prob \\
\hline Gariables & -0.08 & $(0.9333)$ & -0.08 & $(0.9333)$ \\
& None & -2.25 & $(0.0337)$ & -1.2 & $(0.2371)$ \\
& Intercept & -1.24 & $(0.2261)$ & -1.24 & $(0.2261)$ \\
\hline & Intercept and trend & -1.31 & $(0.2014)$ & -1.31 & $(0.2014)$ \\
& None & -3.70 & $(0.001)$ & -2.81 & $(0.0089)$ \\
& Intercept & -4.32 & $(0.0005)$ & -2.76 & $(0.0102)$ \\
\hline Prim. government balance & Intercept and trend & & & & \\
spending & & & & $(0.7293)$ \\
& None & 0.35 & $(0.7293)$ & 0.35 & $(0.0362)$ \\
& Intercept & -2.20 & $(0.0362)$ & -2.2 & $(0.0768)$ \\
\hline Primary balance & Intercept and trend & -1.84 & $(0.0768)$ & -1.84 & $(0.3227)$ \\
& None & -1.01 & $(0.3227)$ & -1.01 & $(0.0587)$ \\
& Intercept & -3.12 & $(0.0044)$ & -1.97 & $(0.043)$ \\
\hline Primary fiscal gap & Intercept and trend & -3.19 & $(0.0038)$ & -2.12 & $(0.1715)$ \\
& None & -1.08 & $(0.2886)$ & -1.4 & $(0.0033)$ \\
& Intercept & -3.22 & $(0.0033)$ & -3.22 & $(0.0001)$ \\
\hline Government revenue & Intercept and trend & -4.53 & $(0.0001)$ & -4.53 & $(0.6758)$ \\
& None & 0.49 & $(0.6279)$ & 0.42 & $(0.062)$ \\
& Intercept & -2.54 & $(0.0186)$ & -1.94 & $(0.101)$ \\
\hline
\end{tabular}

Note: Augmented Dickey-Fuller and Phillips-Perron unit root tests. Sample: 1986-2016, test statistic and p-value (in parenthesis)

Table no. 1, relate us that over the last three decades, some variables such deficit, primary fiscal deficit, government debt, total fiscal, government spending and government revenues are non-stationary. In what regard fiscal balance and fiscal gap, we find that are stationary and the change in the primary fiscal balance is found to be stationary during this period for $10 \%$ confidence interval. However, in case of fiscal gap and fiscal balance, after applying first difference, they are becoming non-stationary. However, given the result of non-stationarity regarding (primary) fiscal balance, we can say that the intertemporal solvency was not thoroughly ensured in Romania during the last three decades. 
The cointegration test between primary deficit and debt is provide in Table 2 and in Table 3 we found the results of Engle-Granger test on co-integration between primary deficit and government debt

Table 2: Johanson test on co-integration between primary deficit and government debt

Johansen

Primary deficit and Debt

\begin{tabular}{|c|c|c|c|c|c|}
\hline Data Trend: & None & None & Linear & Linear & Quadratic \\
\hline \multirow[t]{2}{*}{ 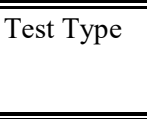 } & No Intercept & Intercept & $\begin{array}{c}\text { Intercept } \\
\text { No }\end{array}$ & $\overline{\text { Intercept }}$ & Intercept \\
\hline & No Trend & No Trend & Trend & Trend & Trend \\
\hline Trace & 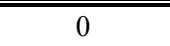 & 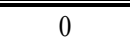 & 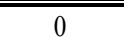 & 0 & 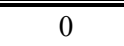 \\
\hline Max-Eig & 0 & 0 & 0 & 0 & 0 \\
\hline
\end{tabular}

*Critical values based on MacKinnon-Haug-Michelis (1999)

Table 3: Engle-Granger test on co-integration between primary deficit and government debt

\section{Engle-Granger}

Null hypothesis: Series are not cointegrated

Cointegrating equation deterministics: $\mathrm{C}$

\begin{tabular}{lcccc} 
Dependent & t-stat & Prob.* & z-stat & Prob.* \\
\hline \hline PBAL & -3.18 & 0.1 & -22.89 & 0.01 \\
DEBT & -2.26 & 0.41 & -16.17 & 0.06 \\
\hline \hline
\end{tabular}

Empirical results point a lack of connection relation between the the stock of debt and primary budget balance. The fact that it isn't cointegration between these two variables emphases that the crisis has led to an additional negative impact on public finance sustainability and the fact that the government's solvency is a difficult task to achieve does not necessarily imply a generalization trend given the real interest rate situations as well as other indicators with a direct impact on the change in the economic cycle, this view being fully supported in the literature as well [33]. In addition to this, results show that time variation of interest rate expectations is plausible given that the Romanian economy underwent changes by preparing for the fiscal consolidation and changes before and after economic crisis and due to the several implementing convergence and stabilization programs that aimed at convergence to fiscal sustainability.

On the other hand, the same researcher shows that there is a close link between the deficit and the budget and that the inter-temporal budgetary balance is assured if the expected real interest rate of interest have positive values [33]. However, we believe that in order for the government to be able to reduce the slippage of the budget, it must focus on strengthening a mechanism that will ensure a political balance that will prevent fiscal measures restoring the balance of the budget to a counter-cyclical position We also find that cointegration is also rejected through the Engel-Granger procedure with a small exception, however, when a quadratic deterministic trend is included in the cointegration equation. This suggest that given the fiscal data from this paper, Romania can consolidate a sustainable public budget process in the long run, economic coordinates allow this, but the preference for pro-cyclicality of adopted policies will impact negative the future generations. Taking into account all these results, we ca say that governmental revenues and expenditures in Romania did not reflect consumption stimulation and increases in this period are driven by a particular component of aggregate demand, with a real problem with the level of investment (on which the growth of the future depends). 
Table 4: Johanson test on co-integration between revenues and expenditures

Revenues and Expenditures

\begin{tabular}{lccccc} 
Data Trend: & None & None & Linear & Linear & Quadratic \\
\hline \hline Test Type & No Intercept & Intercept & Intercept & Intercept & Intercept \\
& & & No & & Trend \\
& No Trend & No Trend & Trend & 0 & 0 \\
\hline \hline Trace & 0 & 0 & 0 & 0 & 0 \\
Max-Eig & 0 & 0 & 0 & 0 & 0 \\
\hline \hline
\end{tabular}

Table 5: The results of Engle-Granger test on co-integration between revenues and spending

Null hypothesis: Series are not cointegrated

Cointegrating equation deterministics: $\mathrm{C}$

\begin{tabular}{|c|c|c|c|c|}
\hline Dependent & $\begin{array}{c}\mathrm{t}- \\
\text { stat }\end{array}$ & Prob.* & z-stat & Prob.* \\
\hline REV & $\begin{array}{c}- \\
2.83 \\
-\end{array}$ & 0.19 & -16.69 & 0.05 \\
\hline GEXNINT & 2.32 & 0.38 & -9.08 & 0.36 \\
\hline
\end{tabular}

*MacKinnon (1996) p-values.

Concerning cointegration attempts, the results do not show full mutual acknowledgment in the confirmation. While Johansen rejects the presence of cointegration, the results of the Engle-Granger test do not reject co-integration. Thus, even if the analysis of the last approach could be meaningless given that it is based on a broad hypothesis of the sample, the first one, however, highlights signs of cointegration of incomes and expenditures.

Analyzing more prudent and making a brief retrospective of both unit-root tests and co-integration results, we can say that the picture on solvency of Romanian public finances since 1986, marked all differences- in the first we have the sample when the communist regime makes important change's on public finances, the second part, after the communism and the area of economic crisis from 2007, and the third part, which include the period of fiscal consolidation and all general efforts to managed the economy to a sustainable growth that can reduce government debt and deficits.

\section{A prospective approach of fiscal sustainability in Romania}

Having in mind the main objective of this paper, in previous section, for a good understanding of Romanian current public finances and challenges and vulnerabilities, we have analyzed the fiscal developments in the last three decades, while at the same time highlighting a general picture of the macroeconomic and budgetary trends. This outline allowed not only a good understanding of the fiscal policy approached by this country, but also the trend of decisions in this area, with a clear delineation of the preference for pro-cyclical or anti-cyclical measures.

In this section, in order to explain and to capture the behavior of the Romanian government decisions in fiscal policy and to capture the implications of policy makers' decisions in what regard the way to fiscal sustainability, we use an estimation model of Romanian public finances.

The period under review is constituted from 1986 to 2016 and taking into account the objective to consolidate a prospective picture of fiscal variables, we used it as a baseline scenario. So, under the desire to bring an innovation to our study, we have simulated starting from the baseline situation, a future trend of fiscal-budgetary variables, which allows an analysis of the consequences of budgetary sustainability in the case of modification in the mandatory factors. 
An interesting analysis of three cases scenarios, highlighting the future trend in public finances is comprised as in (Konings and van Aarle 2011) [34].

Table 1. A designed model of thē Romanian public finances -

$$
\left(\frac{B}{Y}\right)_{t}=\left(1-g r_{t}^{n}\right)\left(\frac{B}{Y}\right)_{t-1}-\left(\frac{D}{Y}\right)_{t}+s f a d J_{t}
$$

Eq. (1)

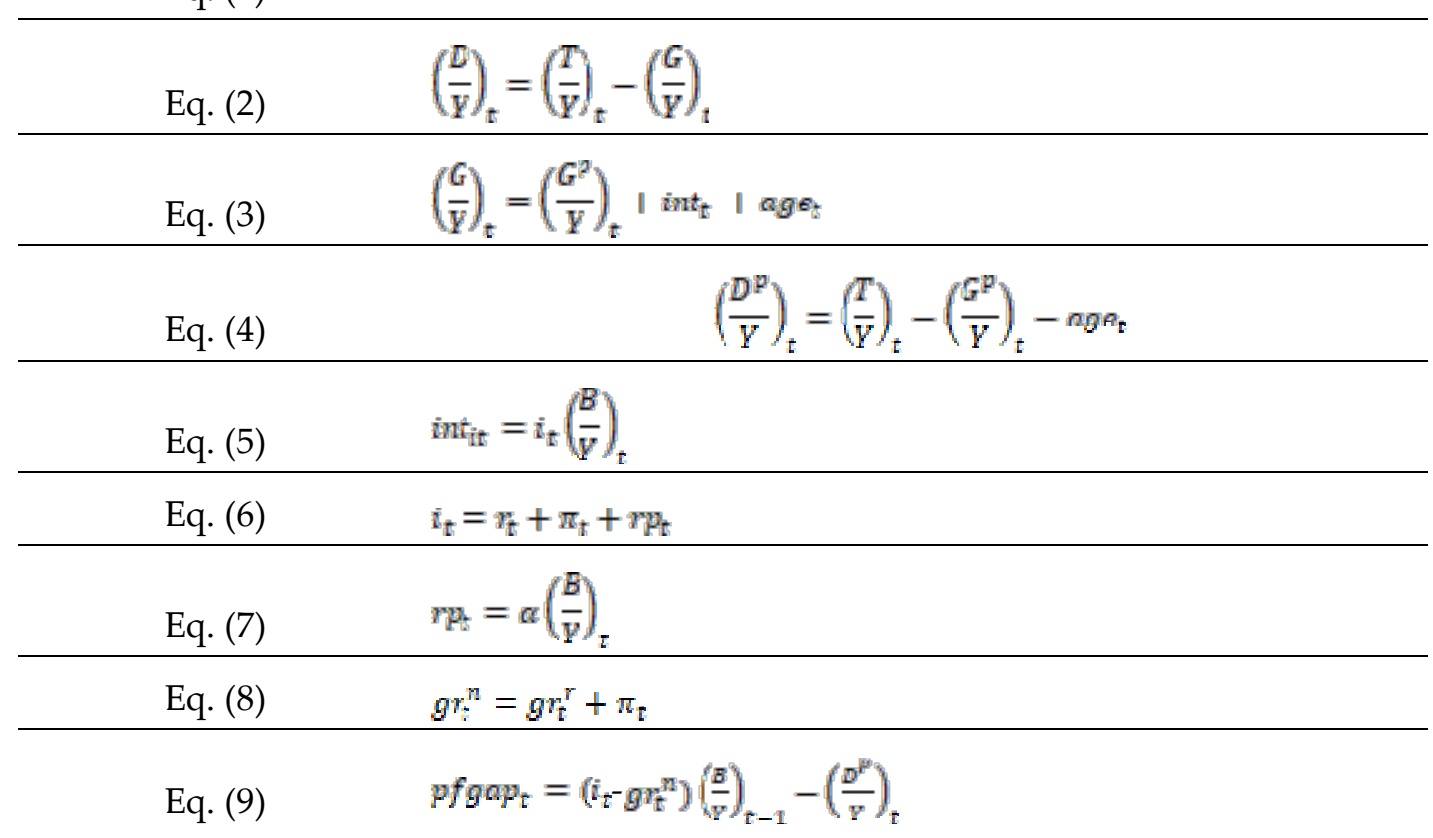

The model proposed by us, use in the first equation a way to ascertain the dynamics of the debtto GDP ratio, (B/Y), as a outcome of $\mathrm{D} / \mathrm{Y}$, the GDP growth rate and a stock-flow adjustment, named (sfadj) in paper.

The equation 2 define the deficit and equations 3, 4. 5, 7, 8. 9 are explained in previous table. Equation 6, relate the nominal interest rate, which is most often calculated according to the inflation rate and is calculated as the sum of the latter and the real interest rate, (real interest rate +expected inflation). After we had run the regression of the Romanian long-term interest rate differential on the level of debt, results suggest a value of $\alpha$ is 0.012 . taking into account the implication of risk premium, means that the debt-dynamics become quadratic in the debt level, since (1)-(7) imply

$$
\left(\frac{B}{Y}\right)_{t}=\left(1-g r_{t}^{n}+r_{t}+\pi_{t}\right)\left(\frac{B}{Y}\right)_{t-1}+a\left(\frac{B}{Y}\right)_{t-1}^{2}-\left(\frac{T}{Y}\right)_{t}+\left(\frac{G^{P}}{Y}\right)_{t}+a g e_{t}
$$


Table 2. Variables employed in data analysis

\begin{tabular}{|c|c|c|c|}
\hline Code & Variable & Definition & Data Source \\
\hline DEBT & $\begin{array}{l}\text { Government debt } \\
\text { (DEBT, \% GDP) }\end{array}$ & Debt owed by a government & \\
\hline FBAL & $\begin{array}{l}\text { Fiscal balance } \\
\text { (FBAL, \% GDP) }\end{array}$ & $\begin{array}{l}\text { The mirror of all budget revenues and } \\
\text { expenditures. In our sample, according to } \\
\text { Equation } 4 . \text { Is defined as difference between } \\
\text { primary fiscal balance and interest payments. } \\
\text { Including in calculation even the equation } 5\end{array}$ & AMECO \\
\hline INT & $\begin{array}{l}\text { Interest payments } \\
\text { (INT, \% GDP) }\end{array}$ & $\begin{array}{l}\text { The amount of interest that a borrower pays to a } \\
\text { lender on a loan each month. }\end{array}$ & AMECO \\
\hline PBAL & $\begin{array}{l}\text { Primary fiscal gap } \\
(\text { PFGAP, \% GDP) }\end{array}$ & $\begin{array}{l}\text { Is defined as an instrument of analyzed the } \\
\text { correlation between the present value of } \\
\text { government obligation, value of all projected } \\
\text { future tax and other receipts. In our sample, } \\
\text { based on equation 9, is presented that positive } \\
\text { gap value indicates the impossibility of primary } \\
\text { balance to stabilize debt at the current level and } \\
\text { to stop debt grow }\end{array}$ & $\begin{array}{l}\text { AMECO } \\
\text { database and } \\
\text { Knoema World } \\
\text { Data Atlas. }\end{array}$ \\
\hline GROWTHN & $\begin{array}{l}\text { Nominal GDP } \\
\text { growth } \\
\text { (GROWTHN, \%) }\end{array}$ & $\begin{array}{l}\text { Equation } 8 \text { explain this variable as the sum of } \\
\text { real growth and the rate of inflation. }\end{array}$ & AMECO \\
\hline LTINT & $\begin{array}{l}\text { Long term interest } \\
\text { rate (LTINT \%) }\end{array}$ & $\begin{array}{l}\text { It refers to long-term government bonds, more } \\
\text { precisely, with a maturity of ten years }\end{array}$ & AMECO \\
\hline $\mathrm{RP}$ & $\begin{array}{l}\text { Risk premium (RP } \\
\%)\end{array}$ & $\begin{array}{l}\text { Indicate rate risk in government bonds and } \\
\text { according to equation } 7 \text {, our model assumes that } \\
\text { depends on the level of debt }\end{array}$ & AMECO \\
\hline INTGROWDIF & $\begin{array}{l}\text { Interst growth } \\
\text { differential } \\
\text { (INTGROWDIF \%) }\end{array}$ & $\begin{array}{l}\text { An essential variable in the dynamics of the debt } \\
\text { ratio; that is, the ratio of government debt to } \\
\text { GDP. Represent the difference between the } \\
\text { interest rate paid on government debt and the } \\
\text { growth rate of GDP and drives the inertial or } \\
\text { "snowball" dynamics of the debt ratio }\end{array}$ & $\begin{array}{c}\text { AMECO } \\
\text { database and } \\
\text { Knoema World } \\
\text { Data Atlas. }\end{array}$ \\
\hline REV & $\begin{array}{l}\text { Government } \\
\text { revenue }(\mathrm{REV} \% \\
\mathrm{GDP})\end{array}$ & $\begin{array}{l}\text { An important instrument of government and } \\
\text { fiscal policy, all sources of public spending } \\
\text { financing }\end{array}$ & AMECO \\
\hline GEXNINT & $\begin{array}{l}\text { Primary } \\
\text { government } \\
\text { spending } \\
\text { (GEXNINT \% } \\
\text { GDP) } \\
\end{array}$ & $\begin{array}{l}\text { According to equation } 3 \text {, this variable includes } \\
\text { an essential element, more exactly, the } \\
\text { expenditures that are related to ageing, being } \\
\text { the sum between these, primary expenditures, } \\
\mathrm{G}^{\wedge} \mathrm{P} / \mathrm{Y} \text { and interest expenditures (in \% of GDP). }\end{array}$ & AMECO \\
\hline REALGROWTH & $\begin{array}{l}\text { Real GDP growth } \\
(\%)\end{array}$ & $\begin{array}{l}\text { Real GDP = GDP / ( } 1+\text { Inflation since base year). } \\
\text { Based on equation } 8 \text {, we find that in what regard } \\
\text { the concept of nominal growth, we use the sum } \\
\text { of real growth and inflation. }\end{array}$ & AMECO \\
\hline INFL & Inflation (\%) & $\begin{array}{l}\text { An increase in the overall price level for both } \\
\text { goods and services, as purchasing power } \\
\text { decreases or an increase in the price level from } \\
\text { one year to the next year. }\end{array}$ & AMECO \\
\hline INT & Real interest rate & $\begin{array}{l}\text { Based on Fisher equation, the real interest rate }= \\
\text { nominal interest rate - the inflation rates }\end{array}$ & AMECO \\
\hline SFADJ & $\begin{array}{l}\text { Stock-flow } \\
\text { adjustment } \\
\text { (SFADJ, \% GDP }\end{array}$ & $\begin{array}{l}\text { Explains the difference between the change in } \\
\text { government debt and the government } \\
\text { deficit/surplus for a given period }\end{array}$ & $\begin{array}{l}\text { AMECO } \\
\text { database and } \\
\text { Knoema World } \\
\text { Data Atlas. }\end{array}$ \\
\hline
\end{tabular}


The current crisis has brought into discussion the determinant role that public finances have in macroeconomic stability. If in the Eurozone, for example, the sovereign debt crisis continues to be on the government agenda, in Romania the current low level of public debt places this issue somewhat outside the sphere of immediate public interest. However, the presence of risks, both at the moment and due to structural changes in relation to international market funding, validates a re-evaluation of this issue.

Even if the public debt path provides a long-term perspective regarding the sustainability of public finances, Romania needs a sustained annual growth in order to keep public debt on a sustainable footing. Also, there are many variables that dictate the path of a viable fiscal consolidation process and much more considerations that need to to be looked at distinctly. For example, a higher interest rate on loans will lead to an increase in the public debt / GDP ratio. An increase of 100 basis points in the real interest rate may add the equivalent of $1.1 \%$ of GDP to the public debt. A $5 \%$ depreciation of the RON against the EUR may add the equivalent of 1\% of GDP to the public debt (expressed in RON). In the short term, the risk of depreciation of the leu can be boosted by both a higher interest rate on loans and an under-expected evolution of the economy and/or achieving a level of budget revenues under the proposed target To simulate the model of Romanian public finances for the period 2016-2046 and analyzing the effects of different changes, we first establish the baseline scenario for the exogenous variables involved in the model, basing its analysis on the situation over the past three decades, more precisely, the period 1986-2016. In base of the initially baseline scenario, we assume initially a $0.5 \%$ decrease (increase) in the real interest rate in order to highlight the implication of sensitivity of the Romania budgetary variables to low changes in the interest rates. In the second scenario, we analyze the effects of growth rate changes, simulate the results that can appear in the case of an improvement (reduction) of the growth rate of $0.5 \%$ compared to the baseline. And finally, we analyze the primary fiscal balance adjustments.

\section{The implication of interest rate changes}

Given the debt levels, debt servicing costs tend to be more sensitive to changes in the effective interest rate and we can say also that is more exposed to inflation. These sensitive changes due to their impact on interest burdens and thereby on the fiscal balance. In figure no. 2, Scenario 1 (2) highlight the relatively high sensitivity of the Romania budgetary variables in some case of small changes in the interest rates. Even if according to the European specificity, we can say that Romania does not have a big debt, the EU27 average being in in 2016-82.5\% of GDP, a share of Greece's debt of 177\% of GDP, Italy 134\% of GDP, $\%$ or Belgium 107\%, we can observe in our results that in a context in which interest rate increases, fiscal sustainability deteriorates compared to the baseline, especially in the long run. This is an interesting finding for Romania, especially as small-debt countries can become insolvent if financial markets do not cover liquidity gaps;

\begin{tabular}{|c|c|c|}
\hline 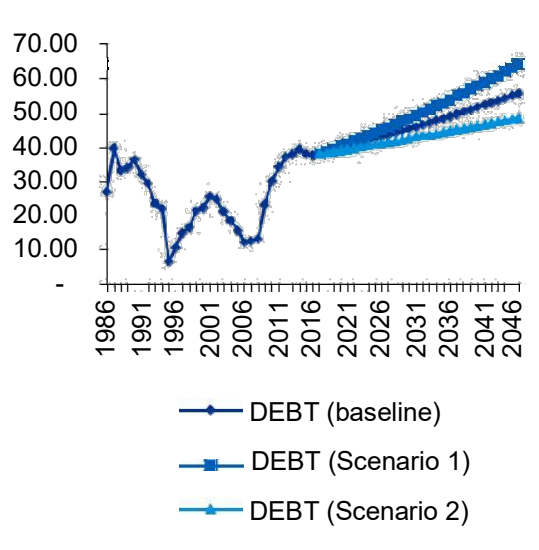 & 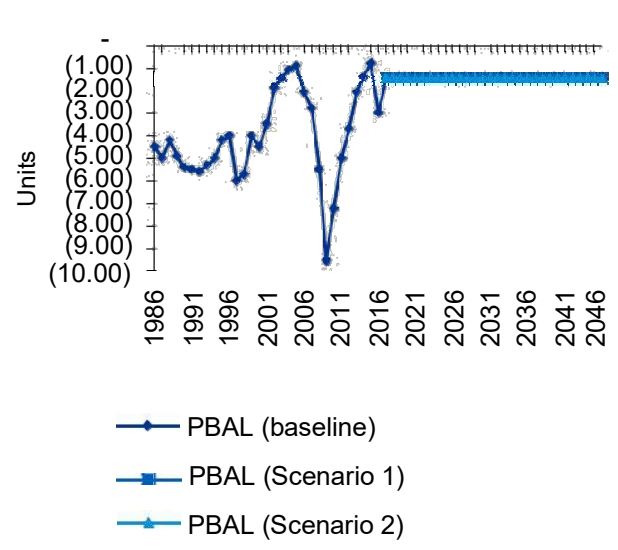 & 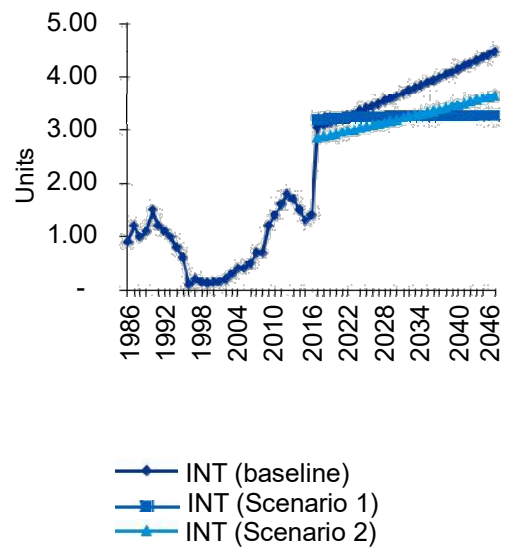 \\
\hline
\end{tabular}




\begin{tabular}{|c|c|c|}
\hline 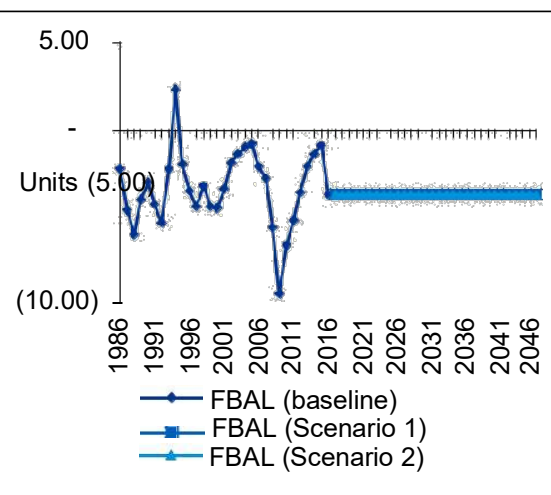 & 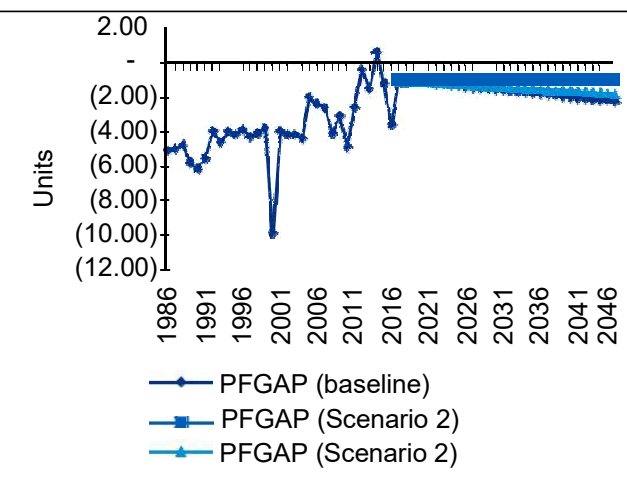 & 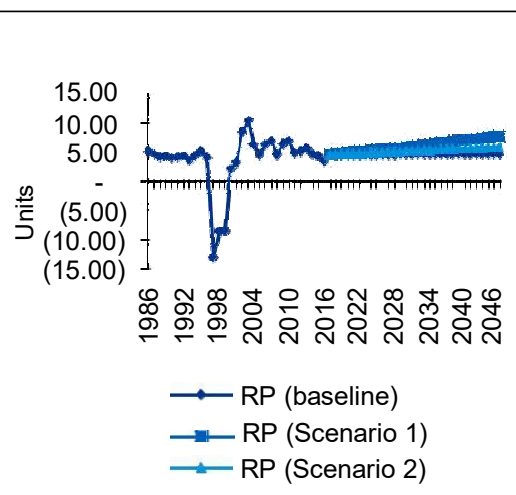 \\
\hline & 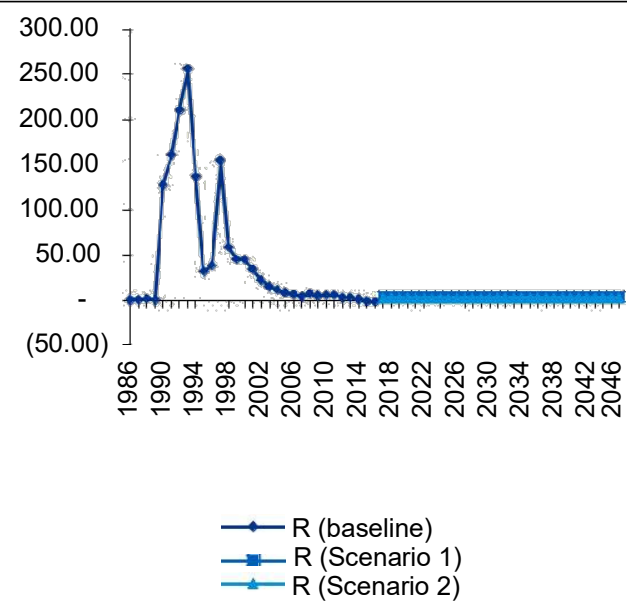 & \\
\hline
\end{tabular}

Figure 2 Baseline scenario Romanian public finances 2017-2046-0.5\% decrease in the interest rate of 0.5\% (case of scenario 1) vs $0.5 \%$ increase in the interest rate case of scenario 2 ).

\section{Implications of growth rate changes}

Scenario 3 (4) simulate the results that can appear in the case of an improvement (reduction) of the growth rate of $0.5 \%$ compared to the baseline. We can observe that any small but sustained changes in the growth path have implied a direct effect on public finances. The impact of growth changes on debt dynamics, get on declining path and all fiscal variables improve. This leads to the conclusion that the correct use of fiscal stimuli, and at the same time the preference for a fiscal policy which consolidates sustainable growth, is not an impossible task to reach in terms of decision-making power, but it raises the political stakes and cost in this area.

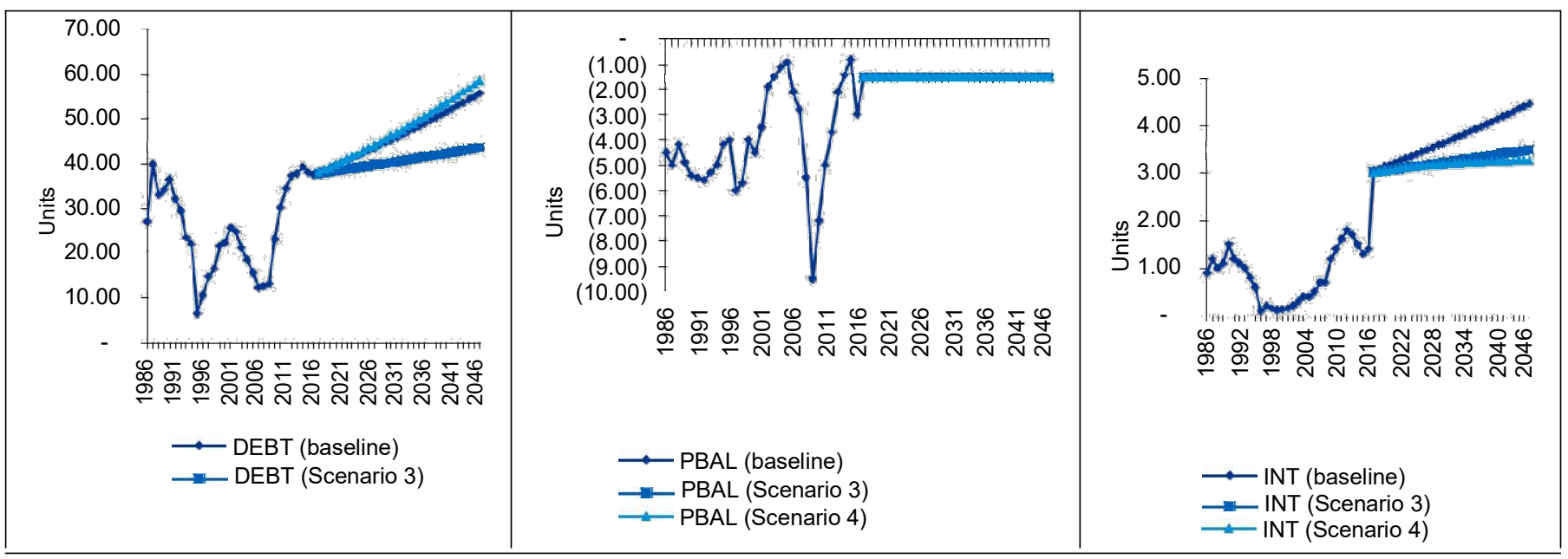




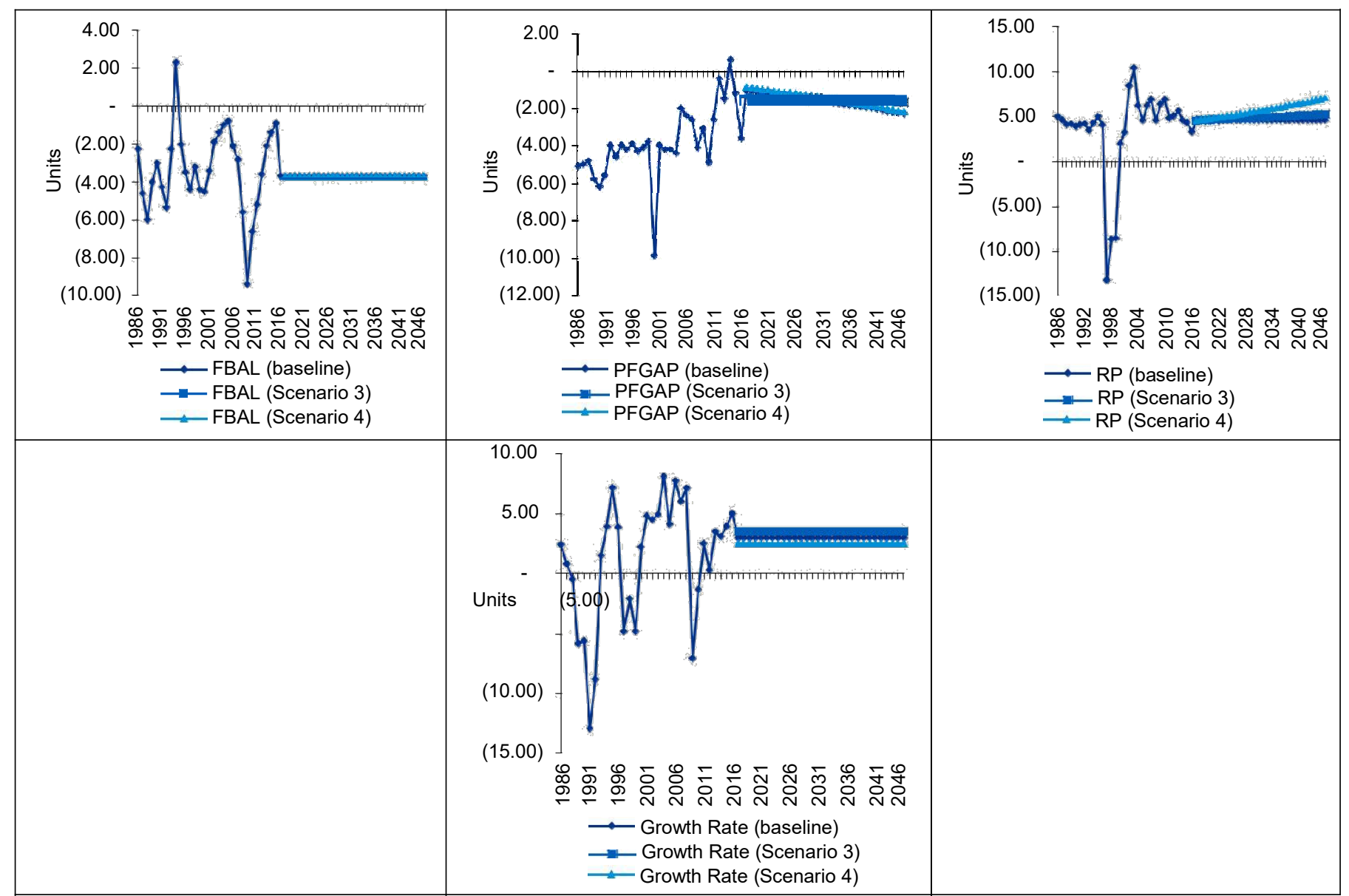

Figure 3 Baseline scenario Romanian public finances 2017-2046 (dark blue lines), 0.5\% increase in the real GDP growth rate of $0.5 \%$ (Scenario 3) vs $0.5 \%$ decrease in the real GDP growth rate (Scenario 4 ).

\section{Primary fiscal balance adjustments}

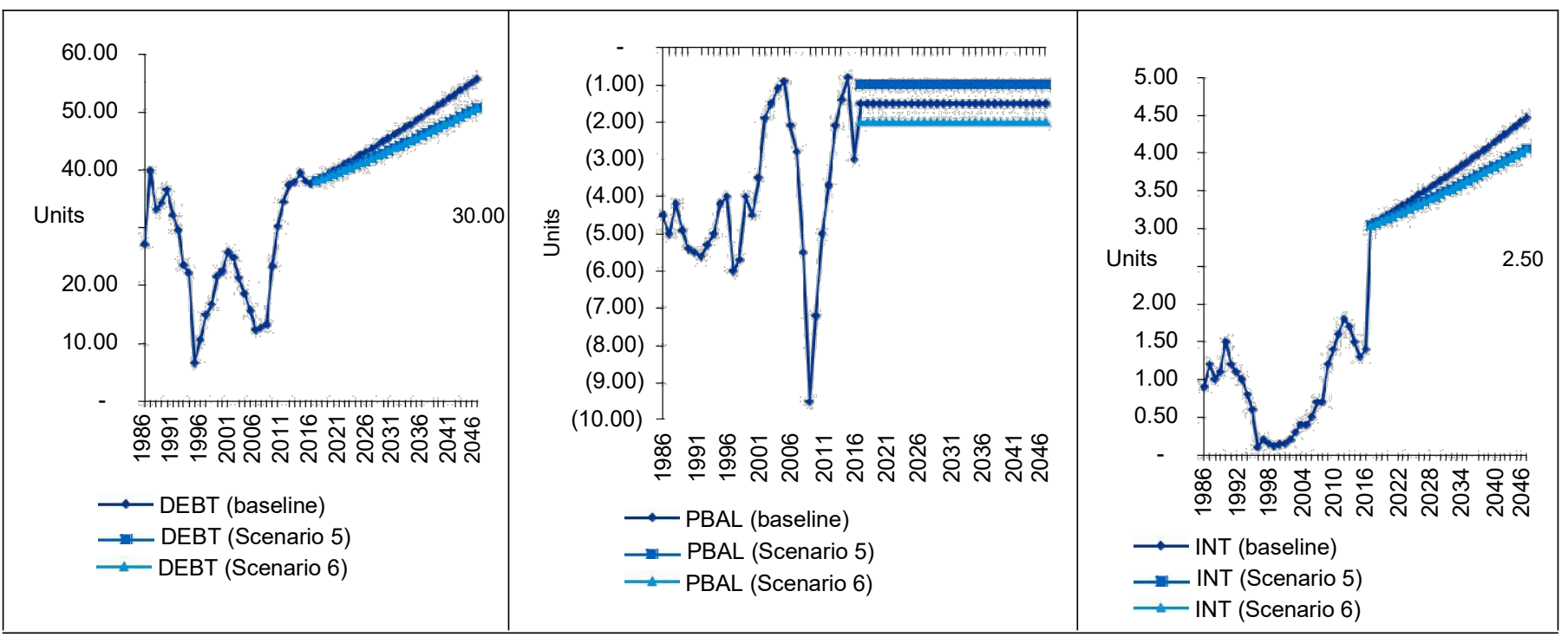




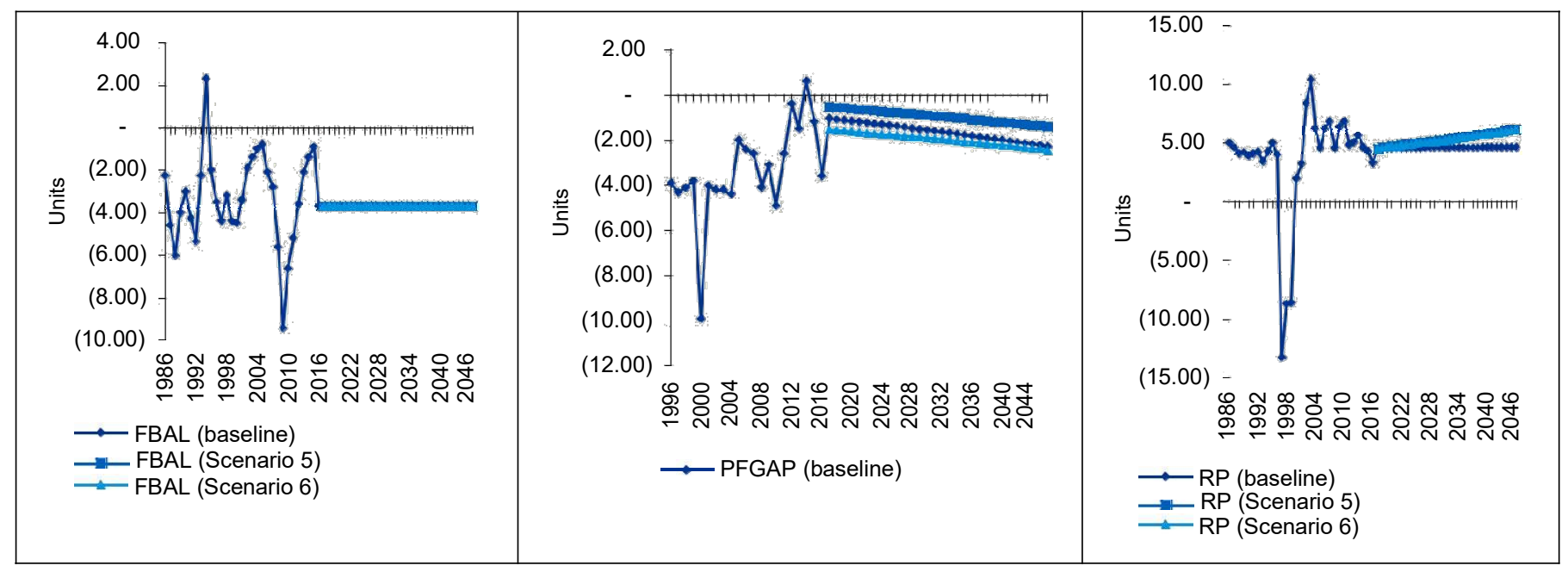

Figure 4. Baseline scenario Romanian public finances 2017-2046, a fiscal consolidation effort of 1\% of GDP during 2017-2046, (Scenario 5,) vs a fiscal spending deterioration of 1\% of GDP during 2017-2046 (Scenario 6).

According to this last scenario analysis, emphasizes the implications of a large sensitivity, predominantly in a long-term perspective of the Romania budgetary situation to small, permanent changes in the primary balance. Making a comparison with the baseline, we can deduce that any deterioration in primary fiscal balances inevitably implies a negative effect on fiscal sustainability. In fact, the results confirm some of the above-mentioned opinions in the specialized literature, emphasizing on the obvious way the importance of correlating fiscal changes on long and medium term with the macroeconomic context and the decisions and strategies for fiscal consolidation.

More than that, the simulation points in a quantitative manner to the clear conclusion that even if the economic situation seems to be on the right way, with a level of debt that is smaller than the EU average, the fiscal conjecture is far from fiscal sustainability.

\section{Discussion and conclusion}

The literature concerning the issue of Romanian public finance sustainability is lax and inconclusive. The link between the way to a sustainable fiscal policy and some variables which regards demographic elements, the costs of ageing population, consequently with the increasing spending on pensions and all social obligations which derives from this, is yet little studied. Even if some empirical studies, highlight that the implication of financial crisis has consolidated a period that was characterized by inadvertently adoption of some wrong models of collective discipline, thus deepening the occurrence of fiscal indiscipline over most European countries, it is not clear what are the most changes and vulnerabilities of public finances and this is due perhaps to the fact that countries are not homogenous.

In this particular sample, we carried out an analysis regarding the Romanian public finance sustainability, by using the retrospective as well as the prospective view. For the first approach, we concentrate mainly on empirical tests on Romanian government solvency during the last three decades, by applying standard unit root and co-integration tests and in order to have a better, general understanding of the behavior of policy-makers, in the second part we use a scenario analysis of budgetary adjustment in the short and medium run under alternative hypotheses. The results of paper bring novelty to the existent empirical literature by studying the relationship between Romanian fiscal policy determinants and the economic conjuncture, from the last three decades, relating the context of the recent financial crisis and investigating the future situation in a prospective view. This approach in a double manner, allowed us to provide a general picture of de facto elements regarding picture of public finances and their correlation with the future of Romanian public finances, with the possible intergenerational effect. 
The overall findings of our analysis point that achieving performance with a volatile European and world-wide volatile macroeconomic environment is extremely difficult and the picture of Romanian public finance sustainability relates to a series of major challenges to the sustainability of public finances, highlighted by both public debt levels and the unsustainable growth rate, accompanied by high inflation in some years. We also find that fiscal gap and fiscal balance are stationary and the change in the primary fiscal balance is found to be stationary during this period for $10 \%$ confidence interval. However, in case of fiscal gap and fiscal balance, after applying first difference, they become non-stationary. Given the result of non-stationarity regarding (primary) fiscal balance, we can say that the intertemporal solvency was not fully ensured in Romania during the last three decades. Results of test for cointegration between debt and primary deficit, suggests that it isn't a cointegration relationship between the primary budget balance and the stock of debt and in terms of time variation of interest rate we can say that the results is presumptive, given that the Romanian economy underwent changes by preparing for the fiscal changes before and after economic crisis and due to the several implementing convergence and stabilization programs that aimed at convergence to fiscal sustainability.

We overall conclude that even if the sustainability of the country has suffered modification in the context of global financial crisis, an important role is also played by the inappropriate diagram of economic policies in past years and lax implementation of fiscal policy. Regarding the main challenges and vulnerabilities in the sustainability of Romanian public finances, the prospective part of this study highlight clearly that this will include/or need to include both instruments for penalizing the policymakers with a preference for pro-cyclical policies, as well as an extended period of fiscal consolidation with the implications of political and social costs.

\section{References}

1. Chan-Lau, Jorge a., and Andre Oliveira Santos. 2010. Public Debt Sustainability and Management in a Compound Option Framework. SSRN Electronic Journal, http://www.ssrn.com/abstract=1536508

2. Woo, Jaejoon, and Manmohan S. Kumar. 2015. Public Debt and Growth. Economica 82(328): 705-39.

3. Radulescu, Doina Maria. 2003. An Assessment of Fiscal Sustainability in Romania. Post-Communist Economies 15(2): 259-76.

4. Săveanu, Tomina Gabriela. 2015. Determinants of Social Responsibility Expenditures of Small and Medium Enterprises From Bihor County. Annals of the University of Oradea, Economic Science Series 24(July): 68.

5. Wilson, Clevo. 2010. Why Should Sustainable Finance Be given Priority? Accounting Research Journal 23(3): 267-80, http://www.emeraldinsight.com/doi/10.1108/10309611011092592

6. Badinger, Harald, and Wolf Heinrich Reuter. 2015. Measurement of Fiscal Rules: Introducing the Application of Partially Ordered Set (POSET) Theory. Journal of Macroeconomics 43: 108-23.

7. Joireman, Jeff, David E. Sprott, and Eric R. Spangenberg. 2005. Fiscal Responsibility and the Consideration of Future Consequences. Personality and Individual Differences 39(6): 1159-68.

8. Neyapti, Bilin, and Zeynep Burcu Bulut-Cevik. 2014. Fiscal Efficiency, Redistribution and Welfare. Economic Modelling 41: 375-82

9. Afonso, António. 2005. Fiscal Sustainability: The Unpleasant European Case. FinanzArchiv 61(1): 19- 44

10. Fatás, Antonio, and Ilian Mihov. 2009. "Why Fiscal Stimulus Is Likely to Work." International Finance 12(1): 57-73.

11. Neaime, Simon. 2015. Sustainability of Budget Deficits and Public Debts in Selected European Union Countries. Journal of Economic Asymmetries 12(1): 1-21.

12. Blanchard, Olivier, Jean-Claude Chouraqui, Robert P. Hagemann, and Nicola Sartor. 1990. The Sustainability Fiscal Policy : New Answers To An Old Questions. OECD Economic Studies 15: 1- 36. 
13. Polito, Vito, and Mike Wickens. 2005. Measuring Fiscal Sustainability. Centre for Dynamic M Acroeconomic Analysis Conference P Apers 44(0): 1-56.

14. Tanner, Evan, and Issouf Samake. 2008. Probabilistic Sustainability of Public Debt: A Vector

Autoregression Approach for Brazil, Mexico, and Turkey. IMF Staff Papers 55(1): 149-82.

15. Pinheiro, Maximiano, and Vanda Geraldes. 2007. MISS: A Model for Assessing the Sustainability of Public Social Security in Portugal. Banco de Portugal Occasional Paper (71), http://www.bportugal.pt/en-US/BdP Publications Research/OP200703.pdf

16. Alho, Juha M., Svend E Hougaard Jensen, and Jukka Lassila. 2008. Uncertain Demographics and Fiscal Sustainability Uncertain Demographics and Fiscal Sustainability.

17. Ewijk, Casper Van, Nick Draper, Harry Rele, and Ed Westerhout. 2006. Ageing and the Sustainability of Dutch Public Finances.

18. Bergman, U.M., M.M. Hutchison, and S.E.H. Jensen. 2016. Promoting Sustainable Public Finances in the European Union: The Role of Fiscal Rules and Government Efficiency. European Journal of Political Economy 44.

19. Landolfo, Luigi. 2008. Assessing the Sustainability of Fiscal Policies: Empirical Evidence from the Euro Area and the United States. Journal of Applied Economics XI(2).

20. Afonso, António, and Christophe Rault. 2008. 3-Step Analysis of Public Finances Sustainability: The Case of the European Union. Papers.Ssrn.Com (908), http://papers.ssrn.com/sol3/papers.cfm?abstract_id=1138608

21. Afonso, António, and Christophe Rault. 2010. What Do We Really Know about Fiscal Sustainability in the EU? A Panel Data Diagnostic. Review of World Economics 145(4): 731-55.

22. Afonso, António, and João Tovar Jalles. 2012. Revisiting Fiscal Panel Cointegration and Structural Breaks in Oecd Countries. ECB Working Paper Series (1465).

23. Afonso, António, and João Tovar Jalles, 2014. A Longer-Run Perspective on Fiscal Sustainability. Empirica 41(4): 821-47.

24. Boiciuc, Ioana. 2015. The Cyclical Behavior of Fiscal Policy in Romania. Procedia Economics and Finance 32(15): 286-91. http://linkinghub.elsevier.com/retrieve/pii/S2212567115013933

25. Talpos, Ioan. Fiscal Policy Sustainability in Romania, Romanian Academy / West University of Timisoara, II(3): 233-243.

26. Mura, Petru-Ovidiu. 2015. Public finance sustainability in Romania. Recent developments. Annals of the University of Oradea, Economic Science Series 24: 87.

27. Patricia, Ana et al. 2014. Sustainability of tax system in Romania. Romanian Academy / West University of Timisoara, II(3): 327-332.

28. Georgescu, George. 2014. Public Debt, Sovereign Risk and Sustainable Development of Romania. Procedia Economics and Finance 8: 353-61.

29. Zaman, Gheorghe, and George Georgescu. 2011. Sovereign Risk and Debt Sustainability: Warning Levels for Romania. (32924): 234-70.

30. Canagarajah, Sudharshan, Martin Brownbridge, Anca Paliu, and Ionut Dumitru. 2012. The Challenges to Long Run Fiscal Sustainability in Romania. World Bank Policy Research Working Paper (5927): 1-32.

31. Tița, Cristina (Bătuşaru), Alexandra (Vasile) Oțetea, and Ilie Banu. 2014. The Importance of a Medium-Term Budgetary Framework in Enhancing the Sustainability of Public Finances in Romania. Procedia Economics and Finance 16: 270-74.

32. Bohn, Henning. 1991. The Sustainability of Budget Deficits with Lump-Sum and with Income-Based Taxation. Journal of Money, Credit and Banking 23(3): 580, http://www.jstor.org/stable/1992692

33. Trehan, Bharat, and Carl E Walsh. 1991. Testing Intertemporal Budget Constraints: Theory and Applications to U.S. Federal Budget and Current Account Deficits. Journal of Money, Credit, and Banking 23(2): 206-23

34. Konings, Joep, and Bas van Aarle. 2011. Sustainability of Belgian Public Finance: Challenges and Vulnerabilities. VIVES - Discussion Paper $\quad N^{\circ} 24: \quad$ 1-16, https://lirias.kuleuven.be/bitstream/123456789/344922/1/VIVES DP24.pdf 